\title{
A FRONTEIRA CULTURAL DO SER SURDO: DIFERENÇA E RESISTÊNCIA EM TEMPOS MODERNOS
}

\section{THE CULTURAL FRONTIER OF THE DEAF BEING: DIFFERENCE AND RESISTANCE IN MODERN TIMES}

Katicilayne Roberta de Alcântara'

Antônio Firmino de Oliveira Neto²

\begin{abstract}
RESUMO: Este artigo discute a fronteira cultural que perpassa a surdez entendida como diferença, objetivando contribuir com o debate sobre fronteira, diferença e algumas teorias presentes nos Estudos Culturais. Nesse sentido, por meio de ensaio teórico os conceitos apresentados por autores como Pesavento (2002), Strobel (2016), Costa (2010), Skliar (1999), Geertz (2012), Prysthon (2001), entre outros, foram incorporados a discussăo. Procurou-se desvincular a ideia da surdez enquanto doença, que precisa de cura, ou seja, entender os surdos como sujeitos que possuem uma língua, identidade e cultura e săo protagonistas de sua própria história. Para isso, o artigo foi dividido em três tópicos. 0 primeiro tópico ajuda na compreensâo dos conceitos relacionados às fronteiras presentes na história da educaçấo dos surdos, e como eles eram estereotipados como (a) normais, o segundo tópico apresenta uma discussāo teórica decolonial baseada nos Estudos Culturais e na compreensăo da diferença surda e, por fim, o terceiro tópico apresenta as formas de comunicaçấo dos sujeitos visuais, enquanto produtores de cultura.
\end{abstract}

PALAVRAS-CHAVE: Fronteira; Surdo; Diferença; Estudos Culturais; Libras.

\begin{abstract}
This article discusses the cultural frontier that permeates deafness understood as difference, aiming to contribute to the debate on frontier, difference and some theories present in Cultural Studies. In this sense, theoretical essay review the concepts presented by authors such as Pesavento (2002), Strobel (2016), Costa (2010), Skliar (1999), Geertz (2012), Prysthon (2001), among others, were incorporated into discussion. Sought to disconnect the idea of deafness as a disease, which needs a cure, that is, to understand the deaf as subjects who have a language, identity and culture and are protagonists of

1 Mestranda no Programa de Pós-Graduaçâo em Estudos Culturais do Campus de Aquidauana (UFMS). Possui Licenciatura em Letras - Língua Portuguesa e Libras pela Universidade Federal da Grande Dourados (2018), Licenciatura em Pedagogia pela Universidade para o Desenvolvimento do Estado e da Regiăo do Pantanal (2011) e Especializaçāo em Educaçăo Especial e Inclusiva pela Faculdade de Educaçáo Săo Luís (2018).

2 Doutor em Geografia, docente da graduaçâo e do Programa de pós-graduaçâo em Estudos Culturais do Campus de Aquidauana da Universidade Federal de Mato Grosso do Sul.
\end{abstract}


their own history. For this, the article was divided into three topics. The first topic helps to understand the concepts related to borders present in the history of education for the deaf, and as they were stereotyped as abnormal, the second topic presents a decolonial theoretical discussion based on Cultural Studies and the understanding of the deaf difference and finally, the third topic presents the forms of communication of visual subjects, as producers of culture.

KEYWORDS: Frontier; Deaf; Difference; Cultural Studies; Brazilian Sign Language (Libras).

\section{INTRODUÇÃO}

Para grande parte dos estudiosos sobre o tema, a fronteira geralmente é discutida com relaçôes aos aspectos físicos e espaciais, mesmo que entendidos por múltiplos sentidos. Contudo, para a discussăo aqui proposta, será adotado um significado que transcende aos aspectos meramente geográficos, políticos ou territoriais. Martin (1997) esclarece que a fronteira trás no seu interior o descontentamento, a mudança, o desejo de um determinado grupo em ser diferente do resto do mundo, como "parte distinta, como elemento de um todo maior". Para isso é necessário pressupor a fronteira como um espaço cultural e social, onde sujeitos de culturas e sociedades diferentes se constroem em suas relaçóes e diferenças.

Pensar em cultura remete a conteúdos plurais, nas relaçôes sociais deles provenientes e como se dâo as formas de comunicaçăo entre os sujeitos. É, portanto, com a preocupaçăo em relaçăo as formas de compreensăo da surdez enquanto diferença, que este trabalho buscará contribuir com tais debates e as teorias que perpassam os Estudos Culturais.

Os sujeitos surdos, suas famílias, pesquisadores e instituiçōes começaram uma árdua luta na busca por efetivaçōes dos direitos dos surdos. Strobel (2009) afirma que na historicidade da educaçâo de surdos houve o predomínio da oralizaçáo, como única forma de possível aprendizagem e integraçâo social. Essa realidade ficou marcada na história da educaçấo de surdos, por considerar que o sujeito surdo possui uma patologia que prejudica na aquisiçăo da linguagem. Portanto, o seu desenvolvimento deve-se pautar na língua oral. Sob esta ótica, médicos, terapeutas, educadores e a própria sociedade, ainda acreditam que, os "gestos" nâo apresentam o status de língua, muito mesmo atinge a supremacia da língua falada.

É possível perceber que nos processos de relaçōes entre surdos e ouvintes as fronteiras se impōem sob diversas maneiras. Elas estăo presentes, tanto nas resistências, quanto nas formas de reconhecimento do outro. Um marco que trouxe visibilidade e garantia de acesso para a comunidade surda brasileira, se deu com a assinatura da Lei da Libras $n^{0} 10.436$, de 24 de abril de 2002, e ainda, por meio do Decreto n 5.626, de 22 de dezembro de 2005, que assegura o uso e a difusăo da Libras. Ambos contribuíram para a construçăo da identidade e cultura dos surdos, permeando açôes e envolvendo o modo de comunicaçâo, predominantemente visual, possibilitando a substituiçâo da oralidade como única forma de integraçâo. 
A língua de sinais se apresenta como o elemento constituinte da diferença cultural, linguística, social e identitária dos surdos. Os movimentos de lutas políticas, por sua vez, se apresentam em prol do seu reconhecimento, da resistência e da visibilidade dos seus direitos, na busca por afastar a visâo construída por séculos de "anormalidade" entre o povo surdo e o ouvinte.

Diante disso, este artigo se apresenta como um ensaio teórico, propondo discutir um olhar epistêmico a partir de autores renomados na área da surdez e dos estudos culturais, onde se objetivam principalmente na decolonialidade, na cultura, nos conceitos relativos às fronteiras que envolvem (ou separam) o surdo e o ouvinte, procurando desfazer diversas epistemes do sujeito surdo enquanto doente, que precisa de cura, ou seja, entendê-lo como sujeito que possui uma língua, uma identidade, uma cultura, e sâo protagonistas de sua própria história.

Essa ancoragem se faz a partir de periódicos, livros e legislaçōes pertinentes à temática, e que foram discutidas a partir das experiências e inquietaçôes dos autores deste artigo. Para isso, săo reforçadas questōes históricas e atuais para um novo questionamento ligado à surdez.

Espera-se contribuir com o debate sobre a temática apresentada e, a partir dos autores revisitados, apresentar novos paradigmas e compreensóes diante dessa discussăo que, por sua vez, se encontra dividida em três tópicos. O primeiro tópico ajuda a compreender conceitos relacionados às fronteiras presentes na história da educaçáo dos surdos e como eram estereotipados como (a) normais, o segundo apresenta uma discussáo teórica decolonial baseada nos Estudos Culturais e na compreensâo da diferença surda e, por fim, o terceiro tópico apresenta as formas de comunicaçâo dos sujeitos visuais, enquanto produtores de cultura.

\section{COMPREENDENDO A FRONTEIRA NA SURDEZ}

Falar de fronteira perpassa a discussāo entre limites, demarcaçōes e diferenças. Porém, para Souza (2014, p. 476), ao discutir fronteira é necessário ir além do dicionário ou dos conceitos meramente territoriais geográficos, políticos ou antropológicos e pressupor um espaço cultural e social. Haja vista que, se torna necessário compreender um espaço de sujeitos, sejam individuais ou coletivos, que se constroem em suas relaçōes e diferenças.

As discussóes sobre este mote vêm se aprimorando no esclarecimento sobre o espaço da fronteira como meio de inter-relaçōes entre as diferenças territoriais, mas principalmente as diferenças temporais, impostas pela identidade e pelo sentimento de pertencimento a grupos, culturas e sociedades. Para isso, é preciso compreender as fronteiras em diversos aspectos e sentidos. Pesavento (2002, p. 36) destaca que:

[...] as fronteiras a partir de uma concepçăo que se ancora na territorialidade e se desdobra no político. Neste sentido, a fronteira é, sobretudo, encerramento de um espaço, delimitaçấo de território, fixaçâo de uma superfície. [...] Com isso podemos ver que, mesmo nesta dimensăo de abordagem fixada pela territorialidade e pela geopolítica, o conceito de fronteira já avança para os domínios daquela construçăo sim- 
bólica de pertencimento a que chamamos identidade e que corresponde a um marco de referência imaginária que se define pela diferença.

O homem, no seu processo de evoluçăo e desenvolvimento, foi além dos territórios, libertando-o dos limites físicos que o prendiam, ou seja, tornando-se independente dos aspectos meramente naturais do relevo, ao mesmo passo que criava outros elementos limitadores e libertadores, relacionados com a sua condiçấo de ser social. Pesavento (2002, p. 36) argumenta que "a fronteira é um limite sem limites que aponta para um além", enfatizando o caráter dialético da condiçăo humana.

Analisada por esse prisma, a fronteira possibilitou o contato com o outro, fortalecendo e criando novos sentidos culturais, onde os limites corroboram para a construçâo de identidades. Lopes (2017, p. 223), aguça a discussăo, argumentando que as diferenças podem aprofundar a desigualdade, pois a fronteira pode ser uma escolha ou uma imposiçăo

\begin{abstract}
[...] estar no front é uma alternativa, uma escolha, mas também uma falta de opçăo, uma violência. Se por um lado, revela uma potência, uma condiçáo de possibilidade, uma vida nova, um devir criança, um devir animal e um devir louco, por outro, evidencia a maneira colonial de tratar essa populaçâo em muitos gradientes de normatividade que transforma a condiçăo de diferença numa profunda desigualdade.
\end{abstract}

As fronteiras que separam os sujeitos, atravessam os produtores de seus discursos. Por vezes elas aparecem, desaparecem, aparecem novamente, tendem a se multiplicar, se disfarçam, mudam de corpo, e se apresentam diante do contato como formas de linguagem. Esses săo, para os surdos, os contornos da fronteira imposta pela sua especificidade. Segundo Strobel (2016, p.52) "para o sujeito surdo ter acesso às informaçôes e conhecimentos, e para construir sua identidade, é fundamental criar uma ligaçăo com o povo surdo em que se usa a sua língua em comum: a língua de sinais."

O fato dos surdos pertencerem à uma sociedade que na sua maioria é composta por pessoas ouvintes, faz com que a língua de sinais, que se caracteriza pela modalidade visual-gestual, acabe se encontrando com as línguas orais que, por sua vez, tem a modalidade oral-auditiva. Por outro lado, o surdo náo é o oposto do ouvinte, como esclarece Skliar (1999, p. 22)“[...] sâo experiências singulares que constituem uma diferença específica. ", que indubitavelmente trazem sinais de segregaçóes, e "negar uma abordagem social, política, histórica e cultural neste território constitui o primeiro nível de discriminaçăo, o mais sutil, sobre o qual depois se tramam todas as demais exclusóes de cidadania, linguística, comunitária, etc." Skliar (1999, p.18). Para entender esse processo é necessária uma breve retrospectiva sobre 0 seu processo histórico.

O surdo sempre foi marcado no tempo com representaçóes do ser diferente. No período egípcio, segundo Costa (2010, p. 19) “a posiçấo-sujeito ocupada pelo surdo năo seria a mesma de um humano, por ele năo falar e por ser incapaz de aprender. " Durante a Antiguidade e por quase toda a Idade Média, as ideias em relaçăo ao surdo permeavam a visăo aristotélica, considerados náo educáveis, anormais, imbecis, como afirma Costa (2010, p. 20) “para Aristóteles, nâo sendo capaz de falar, o 
surdo também năo tinha a possibilidade de ser educado, de construir pensamentos ou de expressar seus sentimentos."

A partir do início do século XVI se iniciam as primeiras discussōes sobre as formas e meio pedagógicos de aprendizagem dos surdos. A deficiência passa a ser vista a partir da análise médica e cientifica. Neste sentido, demonstra Costa (2010, p. 21) "O sujeito surdo passa a ser olhado como apto à linguagem, capaz de comunica-se, de pensar, de expressar sentimentos, um ser moral. Neste período, o foco de ensino/aprendizagem tinha como objetivo a aquisiçăo de conhecimentos e a comunicaçăo com as demais pessoas. O caminho trilhava para a aprendizagem da fala e sua compreensāo.

Os primeiros educadores de surdos surgem com a percepçâo de que o surdo era capaz de pensar e ser ensinado. Pedro Ponce de Leon foi fundador da Escola para Surdos em Madrid, onde "Educou surdos filhos de nobres e os ensinou a falar, ler, escrever e sobre o cristianismo. Trabalhou através da datilologia, escrita e oralizaçâo, e fundou uma escola de professores surdos. " (COSTA (2010, p. 22). Posteriormente, a educaçăo de surdos ainda contou com Juan Pablo Bonet, que desenvolveu o ensino de letras associado ao alfabeto manual.

Os surdos ainda enfrentavam dificuldades com relaçâo ao aprendizado da língua oral e da leitura labial, uma vez que, de acordo com o grau de surdez, o acesso aos espaços de aprendizagem e os métodos utilizados naquela época, nem todos tinham a facilidade em aprender.

Foi entâo que, no século XVII, o abade Charles-Michel de l'Épée se interessou em criar um método de ensino voltado para os surdos, pois para ele, segundo Costa (2010, p. 26) os surdos estavam"[...] reduzidos à condiçâo de animal se nâo chegassem a ser ensinados e cristianizados para que lhe fosse concedida a condiçâo de humanizaçăo."

O método criado por l'Épée foi chamado de "Sinais Metódicos", que consistia no ensino misto da língua francesa com a língua de sinais, conhecida na época como gestos. De acordo com Martins e Lisbāo (2019, p. 208) “[...] o abade Charles-Michel de l'Épée foi sensível ao perceber nas interaçôes entre surdos que o uso de um sistema gestual funcionava bem para a comunicaçâo. " Ainda segundo os registros, após sua morte foi criada a escola Institution Nationale des Sourds-Muets ${ }^{3}$, em Paris.

Infelizmente os "sinais metódicos" nâo foi popularmente aceito nas instituiçôes de ensino por resistência e influência da sociedade europeia, por onde o método se difundiu. As pesquisas e os pesquisadores contrários a este método de ensino organizaram um congresso em Milăo em 1880, em que se discutiu o melhor método de ensino para surdos. Este evento tornou-se um marco negativo para a história,

3 No ano de 1951 o Instituto foi renomeado para Instituto Nacional de Educaçăo dos Surdos - INES com o surgimento da República e a criaçâo da Língua Brasileira de Sinais (LIBRAS). 
O uso de gestos na comunicaçăo com surdos foi banido, dando lugar ao que ficou conhecido como método oral puro: o uso exclusivo da fala sem nenhum espaço para gestos [...]. Esse evento é lembrado com grande pesar pelos surdos, pois os educadores surdos que atuavam na proposta gestualista ficaram proibidos de se manterem nessa funçăo [...] o mundo todo adotou o oralismo como referência, e a partir dele criaram-se práticas educacionais. (MARTINS; LISBẢO, 2019, p. 209).

Neste período as escolas passaram a homogeneizar o método, os surdos náo tinham lugar de opiniáo, sua diferença vista como anormalidade, era mascarada na tentativa de obrigarem à falar. Este período ainda durou um século e ficou conhecido como o "holocausto" para os surdos.

Ao explicar a relaçăo entre os gregos e os bárbaros na Grécia antiga, Hartog (2004) permite uma analogia sobre essa relaçâo conflituosa entre surdos e ouvintes, pois se estes últimos detêm a oralidade, tornada padrâo na forma de comunicaçấo da sua sociedade, os outros estâo fora ou excluídos. Se para os gregos, o homem era um animal político e a pólis lhe dava esta condiçăo, ser um ápolis lhe negava a condiçấo. Na sociedade do ouvinte é a oralidade que lhe permite se incluir na comunicaçăo e quem năo a detém está sujeito a ser considerado mais ou menos que os seus detentores:

Entre os gregos e os outros, a nova fronteira é, desde entăo, antes de tudo política ensinam as Histórias. [...] Desde entăo estrangeiros à cidade, excluídos desse espaço comum, "fora da cidade" (ápolis), em sentido próprio, o tirano e o rei săo, de uma certa maneira, bárbaros, ou se póem do lado do bárbaro. O que será retomado por Aristóteles, no começo de sua política: se o homem é um animal político, quem é por natureza ápolis é ou menos ou mais que homem; [...] fornecem com o par grego/bárbaro, uma visăo política da alteridade. (HARTOG, 2004, p. 101 - 102).

A presunçáo em relaçăo à surdez é problematizada antropologicamente, uma vez que o discurso clínico e da sociedade ouvinte se inclina para a constituiçăo de sujeitos homogêneos, garantidos pela homogeneizaçăo na comunicaçăo, e que essa diferença remete à anormalidade, à solidăo, ao isolamento e ao silêncio.

No Brasil, de acordo com os registros, a história da educaçáo de surdos ocorre em meados de 1855, com a vinda do professor de surdos E. Huet ${ }^{4}$ ao Rio de Janeiro, sendo francês e surdo, sua vinda ao Brasil se deu por meio de uma carta de recomendaçăo a pedido de D. Pedro II. Desta forma, se "concretiza o desejo de fundar o entăo denominado Imperial Instituto de Surdos-Mudos. " (COSTA, 2010, p. 28), já que E. Huet acreditava que ser surdo nâo era impedimento para aprender.

Contudo, mesmo com a sua instalaçáo, a influência do oralismo permanecia alocada em disciplinas ministradas no instituto, como Linguagem articulada e Leitura sobre os lábios. Diante de tantas possibilidades em fazer o oralismo ter força

4 Vários livros que relatam a história da educaçăo de surdos no Brasil apresentam o nome do professor Huet com grafia de maneira errônea, encontramos nos registros Eduard Huet, Ernest Huet, Hernet Huet, uma vez que o mesmo sempre assinava de maneira abreviada, dessa forma utilizaremos E. Huet para nos referirmos a ele, conforme carta manuscrita contendo três páginas em língua francesa de E. Huet a D. Pedro II, disponível em: < http://repositorio.ines.gov.br/ilustra/bitstream/123456789/185/1/Relatorio\%20Huet\%20\%281\%29.pdf>, acesso em 10 de fev.2020. 
no instituto " [...] em 1889 foi enviado ao governo um ofício mostrando os resultados: os alunos de linguagem articulada năo haviam adquirido nenhuma instruçâo, e os alunos de linguagem escrita apresentaram notável adiantamento. " (COSTA, 2010, p. 31).

O período do oralismo permaneceu ainda por anos e, somente em 1925 é que se começou a substituiçăo da "mímica" como meio de comunicaçăo com os surdos, além disso, a datilologia passou a ser utilizada com o alfabeto sendo representado nas máos, "[...] dada a rapidez da contaminaçâo mímica que fazia com que os surdos em poucas horas se comunicassem entre si por esse meio instintivo. " (COSTA, 2010, p. 35).

O fato de E. Huet ser estrangeiro, surdo e vir recomendado para a fundaçăo do instituto, influenciou o modo educacional dos surdos, virando uma tendência internacional. Ainda, existiram outros "defensores da comunidade de surdos" que, segundo Strobel (2016, p.114) "raramente sáo citados aqueles que eram sujeitos surdos, como Berthier, Clerc, Huet, prevalecendo, na maioria, os ouvintes, como, por exemplo, L'Epée, Gallaudet, Sicard, Bonet e outros. " Marcam-se os ouvintes e negam o povo surdo, demonstrando a discriminação para a cultura surda.

Mesmo diante do fracasso do oralismo, por volta de 1970, surge outra abordagem chamada de Comunicaçâo Total,

[...] Embora se centralize ainda no desenvolvimento oral, é menos radical que o oralismo, ao permitir o uso de gestos, mímicas e outros recursos no ensino. Nessa filosofia, tudo vale para a comunicaçáo. O lema dessa abordagem é: o uso de todos os recursos possíveis para o desenvolvimento da pessoa surda e consequentemente da oralidade. (MARTINS; LISBÂO, 2019, p. 214).

Essa abordagem demonstrava fragilidades, pois as interaçōes ocorriam de modo artificial e limitada. Apesar de inúmeros recursos utilizados, os surdos năo apresentavam avanços significativos, impedindo uma construçăo de sentidos e conceitos.

Contudo, conforme Gesser (2009), na década de 1960 a língua de sinais teve o seu status linguístico reconhecido por meio das pesquisas de William Stokoe, com a publicaçâo do primeiro dicionário de Língua Americana de Sinais (ASL). Já no Brasil, destacam-se surdos e ouvintes pesquisadores na área da língua de sinais, como afirma Karin Strobel,

[...] citamos como exemplos os ouvintes Lucinda Ferreira Brito (1986), Ronice Quadros (1995, 2004), Tanya Felipe (2002) e Lodenir Karnopp (2004) e os surdos linguistas Ana Regina Campello (2007) e Shirley Vilhalva (2007), que proporcionaram a valorizaçăo da língua de sinais, dando-lhe status de uma língua legítima do povo surdo. (STROBEL, 2016, p. 55).

Além disso, foram iniciadas novas perspectivas educacionais na busca pelo respeito ao surdo na sua diferença e ao aprendizado da língua de sinais. De acordo com Perlin e Strobel (2006) ainda existem o Bilinguismo, a Pedagogia do Surdo e a Mediaçāo Intercultural. 
Nesse sentido, o bilinguismo deve ser destacado por ganhar espaço e se contrapor ao oralismo de maneira forte. Martins e Lisbâo auxiliam a compreender sobre o bilinguismo, ao afirmarem que:

[...] corresponde à defesa da aprendizagem de duas línguas: a língua de sinais como primeira língua a ser adquirida pela criança surda o mais cedo possível; e a língua oral do país como segunda língua na modalidade escrita. Logo, a escola passou a ser vista como um espaço para a construçăo de conhecimentos culturais através da língua de sinais. (MARTINS; LISBÂO, 2019, p. 217).

Com o reconhecimento da língua dos surdos, a Libras - Língua Brasileira de Sinais foi assinada legalmente no ano de 2002 e regulamentada pelo Decreto 5.626, de 22 de dezembro de 2005, prevendo acessibilidade para esta minoria linguística.

Art. $1^{\circ}$ É reconhecida como meio legal de comunicaçăo e expressăo a Língua Brasileira de Sinais - Libras e outros recursos de expressáo a ela associados.

Parágrafo único. Entende-se como Língua Brasileira de Sinais - Libras a forma de comunicaçăo e expressăo, em que o sistema linguístico de natureza visual-motora, com estrutura gramatical própria, constituem um sistema linguístico de transmissáo de ideias e fatos, oriundos de comunidades de pessoas surdas do Brasil.

O decreto ainda viabiliza o direito à educaçăo bilíngue para os surdos, implementa a Libras no seu uso e difusâo, além de tornar disciplina obrigatória em cursos de licenciatura, fonoaudiologia e formaçăo de professores. Garante ainda, a presença do profissional tradutor intérprete de língua de sinais em espaços educacionais. De acordo com Costa (2010) a Libras confere especificidades ao surdo brasileiro promovendo um lugar social, de pertencimento, de patriotizaçăo.

\section{OS ESTUDOS CULTURAIS E A SURDEZ ENQUANTO DIFERENÇA}

Os estudos culturais têm se destacado desde a sua formaçăo com as contribuiçōes de Raymond Williams, Richard Hoggart e Edward P. Thompson, trazendo a importância de argumentar, criticar, e ainda, clarificar o debate em assuntos cotidianos, a fim de apresentar novas transformaçôes sociais. Segundo Johnson (2006) o movimento, a particularidade, a complexidade e o contexto sâo as principais preocupaçóes dos estudos culturais.

Com isso, o caráter interdisciplinar dos estudos culturais ajuda a compreender como ocorrem essas mudanças de paradigmas, enquanto diferenças culturais frente aos sujeitos surdos. Pensar em sujeitos ignorados, subalternizados, excluídos e marginalizados, significa atentar-se para o fato de eles estarem buscando formas que "garanta voz a sujeitos que anteriormente nâo tiveram direito a voz" (PRYSTHON, 2001, p. 33). Significa ainda, contribuir para a visibilidade no tocante às suas experiências, de maneira que colabore para a formaçăo social, civil e política enquanto sujeito, abrindo espaço para novas formas de conhecer o outro e de ser reconhecido.

Os surdos e a língua de sinais, por longos anos, sofreram discriminaçôes e preconceitos, no que se refere à escolarizaçâo, vida social, vida religiosa e saúde. Nos 
espaços em que se encontram surdos e ouvintes houve, ao longo da história, a ocorrência de situaçōes em que o grupo subordinado se submete, e também resiste às visōes da maioria ouvinte dominante. Como descreve as pesquisadoras surdas Perlin e Strobel:

Nós surdos sempre soubemos que o desmantelamento da obrigaçâo de nos espelharmos na cultura ouvicentrica nos tornaria diferentes, nos tornaria inevitavelmente possuidores de nossa identidade como surdos. Aí está nossa identidade, uma perigosa aventura de pensar do além, na diferença, construir nosso outro, nossa alteridade. (PERLIN; STROBEL, 2006, p. 44).

Uma das situaçôes mais traumáticas, possível de serem elencadas sobre esse grupo é o processo de normalizaçâo com a "cura" da surdez. Como comenta Gesser (2012, p. 84) “[...] os surdos eram todos vistos como débeis mentais, criminosos, loucos, [...] os sinais eram tidos como formas obscenas e pecaminosas". Diante dessa ideologia e reforçando a relaçăo de poder e exclusăo social, a grande maioria dos ouvintes nâo conhecia e nem necessitava conhecer a língua de sinais. Por isso, a Libras foi considerada por tantos anos como mímica, gestos, entre outras formas preconceituosamente consideradas menores no uso da comunicaçâo.

Diante disso, após a legalizaçâo da Libras, a visibilidade nos processos comunicativo das comunidades surdas se tornou maior por todo o Brasil, pois, ao valorizar a Libras como um sistema social, estabeleceu-se um vínculo que "valoriza a diferença, estabelece uma espécie de valor positivo para sociedades culturalmente mais heterogêneas". (PRYSTHON, 2001, p. 43).

Por sua vez, as línguas de sinais, passaram a ser "consideradas línguas naturais e, consequentemente, compartilham uma série de características que lhes atribui caráter específico e as distingue dos demais sistemas de comunicaçâo [..], portanto, [...] năo como um problema do surdo ou uma patologia da linguagem" (QUADROS; KARNOPP, 2004, p. 30). Desta forma é imprescindível a defesa da língua de sinais como instrumento que assegura aos seus usuários o direito a um mundo coletivo e social, entrelaçando as identidades e o seu pertencimento nas mais variadas culturas.

O conceito corriqueiramente utilizado para cultura é o de práticas simbólicas de um determinado grupo, como literatura, música, língua, dança, religiăo, teatro e vestuários, dentre outros. Segundo Geertz (2012) cultura seria uma teia de significaçôes compartilhada por um grupo de humanos. Entende-se assim, cultura como os discursos proferidos a partir dos grupos em contato com a sociedade e seu conhecimento. Geertz (2012, p. 4) reverbera também que a "cultura ainda pode ser uma vertente para a criaçăo de novas ideias, atos, emoçōes e valores", a partir das açôes do grupo que a cerca. Nesse sentido, é possível compreender a existência de uma cultura surda, advinda do compartilhamento da língua, da experiência visual, da traduçăo cultural, dentre outros meios que fundamentam a comunicaçăo e as relaçôes entre os sujeitos surdos e deles com os sujeitos nâo surdos.

Para o melhor entendimento do que seria a cultura surda, Strobel (2016, p.29), esclarece que ela também pode ser compreendida como "o jeito de o sujeito surdo entender o mundo e de modificá-lo a fim de torná-lo acessível e habitável, ajus- 
tando as suas percepçōes visuais". É importante destacar que a cultura surda se entrelaça aos que compartilham de um interesse comum, seja por normas, comportamentos e valores.

Portanto, a partir dos esclarecimentos de Strobel (2016), pode-se deduzir que a cultura surda é demonstrada nas açôes que envolvem o seu modo de comunicar predominantemente visual, e por meio da língua de sinais. Ela também reconhece a luta do grupo e suas produçōes, como a literatura, poesia visual, teatro, uso das tecnologias, vida social e esportiva.

Com isso, a busca por espaços e por representatividade se faz mais forte. Hartog (2004, p.23), escreveu que "a fronteira se encontra no próprio movimento de fechamento e abertura, espaço entre dois, em que os viajantes-tradutores podem agir, para o melhor ou o pior". A analogia ao raciocínio do autor, induz ao entendimento de que os surdos podem ocupar diferentes espaços sociais, mesmo que ele năo esteja encaixado dentro do sistema normativo, hegemônico, determinado pelos sujeitos ouvintes e considerado como padrâo pela sociedade. Assim, em consonância a essa reflexăo, Pesavento (2002, p.37) afirma:

\begin{abstract}
Se a fronteira cultural é trânsito e passagem, que ultrapassa os próprios limites que fixa, ela proporciona o surgimento de algo novo e diferente, possibilitado pela situaçăo exemplar do contato, da mistura, da troca, do hibridismo, da mestiçagem cultural e étnica. [...] a fronteira como conceito possibilitador para se encontrar novos sujeitos, novas construçôes, novas percepçóes do mundo.
\end{abstract}

Dessa forma, vislumbra-se o rompimento de uma fronteira que se confronta na alteridade, na relaçâo entre "nós" e os "outros" e vice-versa, na promoçăo do grupo social e de suas interaçôes, trocas, açôes, etc. A realidade atual aponta para uma nova era de produçâo do Outro, como afirma Skliar (2003, p. 41) "nâo se trata, já, de matá-lo, devorá-lo ou seduzi-lo, nem de enfrenta-lo ou rivalizar com ele, também năo de amá-lo ou odiá-lo, agora primeiro, trata-se de produzi-lo". Pensando no surdo, na sua singularidade, sua visualidade.

\title{
PRODUÇÕES CULTURAIS DOS SUJEITOS VISUAIS
}

A partir das perspectivas pós-coloniais e dos discursos dos grupos minoritários presentes na sociedade, é possível perceber a voz dos sujeitos que deles fazem parte. Por isso, a construçáo de identidade dos sujeitos surdos se faz a partir do momento em que eles se tornam protagonistas de suas produçōes, de suas experiências, e também, na sua formaçâo enquanto sujeito, reformulando a situaçấo de agentes passivos, para agentes participantes, que segundo Brah (2006) pode ser entendido como:

O "eu" e o "nós" que agem năo desaparecem, mas o que desaparece é a noçăo de que essas categorias săo entidades unificadas, fixas, e já existentes, e năo modalidades de múltipla localidade, continuamente marcadas por práticas culturais e políticas cotidianas. (BRAH, 2006, p. 361). 
Essa modificaçăo de estado dos sujeitos com relaçăo à agência no sentido, conforme argumentado por Brah, começa a partir do momento em que eles mudam seus próprios pensamentos e de seus pares. Spivak (2010, p.41) cita que "a transformaçăo da consciência" começa a partir do momento em que esses sujeitos discutem temas relacionados às suas experiências e buscam estratégias para construir narrativas coletivas, manifestando-se de forma cultural, por exemplo. Pode-se complementar esta ideia associando-a à fala de Jodelet (1989, p. 34):

Partilhar uma ideia ou uma linguagem é também afirmar um vínculo social e uma identidade. A partilha serve à afirmaçăo simbólica de uma unidade e de uma pertença. A adesăo coletiva contribui para o estabelecimento e o reforço do vínculo social. (apud FEIX, 2017, p. 5)

A identidade năo é algo pronto, mas é um processo em constante transformaçăo, que se constrói pela diferença, influenciada pela subjetividade, no modo em que o sujeito atua no mundo. Um conceito relacionado intrinsecamente ao de identidade é o da representaçâo, uma visăo consciente, presente na mente das pessoas ou de um grupo.

Os sujeitos surdos necessitam se expressar por meio de sua língua e seus direitos precisam ser respeitados, essa é uma condiçăo sine qua non, tanto quanto para tantas outras minorias existentes na sociedade. Como cita Skliar (1999, p. 24) “[...] Dar lugar às narrativas surdas sobre a surdez constitui, dessa forma, um processo de desouvintizaçâo."

Para Brah (2006, p. 337), “é importante que o Estado seja sensível à pluralidade de necessidades entre seus cidadăos. Mas precisamos estar atentos à maneira como as 'necessidades' săo construídas e representadas em vários discursos". Isso chama a atençấo para o cuidado que o Estado deve ter em atendê-los de maneira heterogênea.

Em consonância, os modos de vida das pessoas sâo transformados cada vez mais pelas mídias e as tecnologias, promovendo um efeito acelerado, em respeito as relaçóes pessoais. Para Sarlo (2016) a relaçâo de ideologias transmitidas por essas tecnologias e meios de comunicaçăo em massa atribuem representaçôes e sentidos para suas significaçōes, reforçando aspectos culturais que se encontram com os pensamentos e as açōes dos sujeitos. "A esfera midiática introduziu inúmeras modificaçōes na apresentaçáo dos problemas que magnetizam a sociedade [...] alterou-se a relaçăo entre os fatos que afetam a todos os cidadâos [...]" (SARLO, 2016, p. 123).

A comunicaçáo conecta os significados entre os sujeitos, principalmente no caso dos sujeitos surdos, que necessitam serem vistos. O desenvolvimento de resistências para a comunicaçâo e a acessibilidade com artefatos ${ }^{5}$ materiais da vida cotidiana, servem para mitigar as falhas ou mesmo as imposiçôes da sociedade, conforme comenta Sarlo (2016):

5 Artefatos nâo se refere apenas a materialismos culturais, mas se refere àquilo que na cultura constitui produçōes do sujeito que tem seu próprio modo de ser, ver, entender e transformar o mundo (Strobel, 2016). 
[...] a democracia de opiniăo é invocada pelos meios audiovisuais que precisam dela como sustento, ao mesmo tempo que reproduzem suas condiçóes de emergência, e ela é convocada como antídoto das falhas da democracia representativa e como socorro da opiniăo pública (SARLO, 2016, p. 124).

A linguagem transmitida nos meios audiovisuais apresenta formas rápidas e icônicas da comunicaçâo, servindo como instrumentos de trocas culturais, de ampliaçâo do léxico, tanto em língua portuguesa, como em Libras e de acesso às informaçôes e comunicaçôes, que auxiliam na construçâo dos sujeitos. Conforme reforça Strobel (2016):

Há artefatos culturais materiais resultantes das transformaçôes da natureza pelo trabalho humano, e sua utilizaçâo é condicionada ao enleio do comportamento cultural dos povos surdos, que auxiliam na acessibilidade da vida cotidiana de sujeitos surdos. (Strobel, 2016, p. 94).

Assim, compreender que os meios, pelos quais os sujeitos se comunicam, sâo os espaços privilegiados cercados de cultura. A literatura, as histórias, as piadas, o teatro, também são formas expressar a cultura surda. Outro exemplo muito utilizado pelos surdos, sâo as redes sociais como Facebook, Youtube, WhatsApp, chats da internet, ICOM.

Além dos artefatos utilizados para a comunicaçăo dos surdos, indaga-se como eles têm acesso nos espaços sociais comuns, como em congressos, faculdades, shows, teatros, bares, igrejas, cinemas, julgamentos, entre outros. Embora assegurado pelo Decreto $n^{\circ}$ 5.626/05, apenas alguns desses casos contam com a presença de tradutores intérpretes de Libras. Porém, quando nâo há essa disponibilidade de profissionais que atendam os direitos dos surdos, percebe-se uma enorme lacuna que que dificulta ao surdo o pleno exercício de sua cidadania. Almeida (2006) argumenta que a influência do hegemonismo ouvinte deixa os surdos sem condiçōes de serem informados, instruídos e de se divertirem.

\section{CONSIDERAÇÕES FINAIS}

Este artigo oportunizou esclarecer conceitos relacionados a fronteira, e ainda destacar a fronteira como um espaço cultural e social, onde sujeitos constroem suas relaçōes e diferenças. Foi possível perceber ainda que o homem, neste caso surdo, é um ser de relaçōes intersubjetivas, sociais e históricas, construído e influenciado pela sua trajetória histórico-cultural, mas nâo incapaz de desenvolver seus próprios discursos. Pode-se ainda, esclarecer conceitos no tocante à normalidade desses sujeitos, percebendo que, ao longo dos anos, os sujeitos surdos, diante da subalternizaçâo imposta pelos ouvintes, criaram maneiras de poderem ser vistos e ouvidos pela sociedade nas diferentes partes do mundo.

Também foi proposto um debate a partir das teorias baseadas nos Estudos culturais e na compreensâo da diferença surda, visto que os surdos entendem, modificam e tornam acessível o mundo a partir de suas percepçôes visuais atreladas a cultura surda, que se dá por meio da língua de sinais. 
Por fim, foram apresentadas formas de comunicaçăo dos sujeitos visuais, enquanto produtores de cultura. Visto que, os avanços legais e tecnológicos proporcionaram aos surdos a difusâo e o uso da Libras no Brasil, oportunizando uma aproximaçăo maior com seus pares, ampliando o acesso às informaçóes que, de modo mais rápido, criou uma maior autonomia e participaçâo social.

No entanto, o reconhecimento das necessidades comunicacionais dos surdos ainda é algo que apresenta barreiras, uma vez que, por trás de todos os contextos envolventes, ainda existem interesses sociais e econômicos que freiam as políticas públicas no atendimento dos direitos e das necessidades do acesso à cultura para os surdos. Diante disso, é importante ressaltar que năo se procurou esgotar as possibilidades de discussóes sobre a temática, esperando ter contribuído para fomentar novas pesquisas e que novas proposiçōes teóricas sejam discutidas a posteriori.

\section{REFERÊNCIAS}

ALMEIDA, W. G. A televisâo e a comunidade surda: um olhar sobre as diferenças. Comunicaçāo \& Informaçâo, v. 9, n.1, p. 53-61, 2006.

BRAH, A. Diferença, Diversidade, Diferenciaçăo. Cadernos Pagu. n²6, p. 329-376. 2006.

BRASIL. Lei no 10.436 de 24 de abril de 2002. Dispóem sobre a língua Brasileira de Sinais - Libras e dá outras providências. Diário oficial da República Federativa do Brasil. Brasília, DF. Disponível em: <http://www.planalto.gov.br/CCIVIL_03/ Leis/2002/L10436.htm>. Acesso em: 20 Dez. 2019.

BRASIL. Decreto 5.626 de 22 de dezembro de 2005. Regulamenta a Lei 10.436 de 24/04/2001 e o artigo 18 da Lei no 10.098, de 19 de dezembro de 2000. Diário oficial da República Federativa do Brasil. Brasília, DF. Disponível em: <http://www. planalto.gov.br/ccivil_03/_ato20042006/2005/decreto/d5626.htm.> Acesso em: 20 Dez. 2019.

COSTA, J. P. B. A Educaçâo do surdo ontem e hoje: posiçâo sujeito e identidade. 1. ed. Campinas - SP: Mercado de Letras, 2010.

FEIX, I. Representaçōes sociais, memória e cultura: a sociedade de consumo e seus estilos de vida imaginados. In: XL Congresso Brasileiro de Ciências da Comunicação, 2017, Curitiba. $40^{\circ}$ CONGRESSO BRASILEIRO DE CIÊNCIAS DA COMUNICAÇÂO UNIVERDIDADE POSITIVO - UP - Curitiba - PR, 2017.

GEERTZ, C. A interpretaçâo das culturas. Rio de Janeiro: LTC, 2012.

GESSER, A. LIBRAS? Que língua é essa? Crenças e preconceitos em torno da língua de sinais e da realidade surda. Sáo Paulo: Parábola Editorial, 2009.

A. O ouvinte e a surdez: sobre ensinar e aprender a Libras. I. ed. Săo Paulo: Parábola Editorial, 2012. 
HARTOG, F. Memória de Ulisses: narrativas sobre a fronteira na Grécia antiga. Traduçâo de Jacyntho Lins Brandăo. Belo Horizonte: UFMG, 2004.

JOHNSON, R. O que é, afinal, Estudos Culturais?. In. da SILVA, T. T. (org). O que é, afinal, Estudos Culturais?. Belo Horizonte, Autêntica, 2006.

LOPES, E. B. Afetos de uma ilha de resistência ao poder do sistema-mundo. In. GOMES, A. R., MENEZES, M. A. de \& GONZÁLEZ, Jose Marín. Novas epistemologia e narrativas contemporâneas. Campo Grande: Life Editora, 2017.

MARTIN, A. R. Fronteiras e Naçōes. 3a ed. Săo Paulo: Editora Contexto, 1997.

MARTINS, V. R; de O., LISBĂO, S. L. Libras no contexto educacional. In. Lacerda, C. B. F. de; SANTOS, L. F. dos (Org.); MARTINS, V. R. O. (Org.). Libras: Aspectos Fundamentais. 1. ed. Curitiba: Intersaberes, 2019.

PERLIN, G; STROBEL, K. Fundamentos da educaçāo de surdos. Florianópolis: UFSC, 2006 .

PESAVENTO, S. J. Além das fronteiras. In: Maria Helena Martins. (Org.). Fronteiras Culturais. Porto Alegre: Ateliê Editorial, 2002.

PRYSTHON, A. Mapeando o pós-colonialismo e os estudos culturais na América Latina. Revista da ANPOLL, v. 1, n. 10, 2001.

QUADROS, R. M. de; KARNOPP, L. Língua de sinais brasileira: estudos linguísticos. ArtMed: Porto Alegre, 2004.

SARLO, B. Paisagens imaginárias: intelectuais, arte e meios de comunicaçâo. Săo Paulo: Edusp, 2016.

SKLIAR, C. A invençâo e a exclusâo da alteridade" deficiente" a partir dos significados da normalidade. Educaçâo \& Realidade, v. 24, n. 2, p. 15-32, 1999.

C. A educaçấo e a pergunta pelos Outros: diferença, alteridade, diversidade e os outros "outros". Ponto de Vista: Revista de educaçâo e processos inclusivos, n. 5, 37-49, 2003.

SPIVAK, G. Pode o subalterno falar? Traduçâo Sandra Regina Goular Almeida, Marcos Pereira Feitosa, André Pereira Feitosa. Belo Horizonte: UFMG, 2010.

SOUZA, M. J. (2014). Fronteiras Simbólicas - Espaço de Hibridismo Cultural, Uma Leitura De Dois Irmáos, De Milton Hatoum. Letrônica, Porto Alegre, v. 7, n. 1, p. 475-489, 2014.

STROBEL, K. História da educaçâo de surdos. Universidade Federal de Santa Catarina. Florianópolis, 2009. $\overline{\mathrm{UFSC}}, 2016$.

K. As imagens do outro sobre a cultura surda. 4. ed. rev. Florianópolis: Ed. da 